\title{
The Materiality of Odors: Experiencing Church Burials and the Urban Environment in Early Modern Northern Sweden
}

\author{
Titta Kallio-Seppä (D) Annemari Tranberg
}

Accepted: 10 July 2019 /Published online: 30 September 2020

(C) The Author(s) 2020

\begin{abstract}
Archaeological material from early modern Sweden reveals that material and social meaning was intertwined in townscape odors; that is, odors and their association with unhygienic conditions affected the physical structure of the town, its material culture, and different traditions in the use of "townspace." During the latter half of the 18th century, the town of Oulu suffered from unpleasant smells related to ponds and wet areas, and the odor of decomposing flesh from under-floor church burials greeted church visitors, despite the tradition of placing fragrant plants inside coffins. In the 18th century the town underwent deliberate changes: the ponds were drained and filled, burials under the church floor were prohibited, and one of the first graveyards located outside the town and separate from the church was constructed. These actions to change the town's "smellscape" reflect emergent notions of regularity and cleanliness related to the Age of Enlightenment.
\end{abstract}

Extracto El material arqueológico de la Suecia moderna temprana revela que el significado material y social estaba entrelazado en los olores del paisaje urbano; es decir, los olores y su asociación con condiciones antihigiénicas afectaban la estructura física de la ciudad, su cultura material y las diferentes tradiciones en el uso del "espacio urbano". Durante la

T. Kallio-Seppä $(\bowtie) \cdot$ A. Tranberg

Department of Archaeology, University of Oulu, PO Box 8000, FI-90014 Oulu, Finland

e-mail: titta.kallio-seppa@oulu.fi segunda mitad del siglo XVIII, la ciudad de Oulu sufría olores desagradables relacionados con estanques y áreas húmedas, y el olor a carne en descomposición de los entierros debajo del piso de la iglesia era a bienvenida para los visitantes de la iglesia, a pesar de la tradición de colocar plantas fragantes dentro de ataúdes. En el siglo XVIII la ciudad sufrió cambios deliberados: se drenaron y rellenaron los estanques, se prohibieron los entierros debajo del piso de la iglesia y se construyó uno de los primeros cementerios ubicado fuera de la ciudad y separado de la iglesia. Estas acciones para cambiar el "paisaje olfativo" de la ciudad reflejan nociones emergentes de regularidad y limpieza relacionadas con la Era de las Luces.

Résumé Le matériel archéologique des débuts de la Suède moderne met en évidence que la signification matérielle et sociale était étroitement liée aux odeurs du paysage urbain, à savoir que les odeurs et leur association à des conditions non hygiéniques affectaient la structure physique de la ville, sa culture matérielle et les différentes traditions d'utilisation de « l'espace urbain ». Durant la dernière moitié du 18ème siècle, des relents désagréables liés aux étangs et marais affligeaient la ville d'Oulou, et la puanteur de la chair en décomposition provenant des enterrements sous le sol de l'église accueillait les visiteurs qui s'y rendaient, en dépit de la tradition des plantes odorantes placées dans les cercueils. Au 18 ème siècle des réformes ciblées furent mises en œuvre par la ville : les étangs furent vidés puis comblés, les enterrements sous le sol de l'église furent interdits et l'un des premiers cimetières situés à 
l'extérieur de la ville et séparés de l'église fut construit. Ces actions visant à modifier le «paysage olfactif» de la ville reflètent des notions de régularité et de propreté liées au Siècle des lumières.

Keywords smellscape $\cdot$ macrofossils $\cdot$ under-floor church burials · odors · Finland · Oulu $\cdot$ social memory . olfactory world

\section{Introduction}

The history of smell is often related to either the environment or culture, but these environmental and cultural dimensions of odor cannot be separated (Jenner 2011:348-349). The focus of this article is on "miasmatic" smells; that is, the belief that diseases are spread through foul-smelling air. Such odors form "smellscapes" that are based on environmental features and social and cultural traditions related to the use of "townspace," especially sacred space in churches, with the 17th- and 18th-century Swedish town of Oulu, now in modern Finland, used as the main example (Fig. 1). The tradition of placing burials beneath church floors started in the Middle Ages and lasted until the 18th century. At first the practice was limited to clergymen, but during the 17th and 18th centuries it became more common, since anyone could purchase a grave site under the church (Paavola 1998). In Oulu there is a clear distinction between the seasons, with cold winters and warm summers, and during the summer months parishioners complained that the foul odor of decomposing bodies made church visits especially unpleasant.

Ponds in the town and close to the church were also said to emit unpleasant smells during the warmer months. Wet areas also made the town's streetscape irregular. Both the decomposing burials and the ponds caused unpleasant smells in the public and private parts of the town. Complaints about the odors affected the social interactions among the residents, how the town grid was formed, and how the space was used, and it brought changes in burial customs during the 18th century. All these changes can be linked to the ideas of the Age of Enlightenment, an 18th-century period when knowledge and reason became important, and people assumed more power over nature. During the Enlightenment more attention was paid to the senses and the way people thought about them, and efforts to eradicate smells are reflected in more regular, efficient, organized, and sanitary town physical spaces (Leone 1999; Matthews et al. 2002; Tarlow 2007; Reinarz 2014).

One of the strongest influences on efforts by urban planners to manage foul odors was the fear of miasma. Foul emanations from soil, air, and water were thought to poison the air, and until the end of the 19th century bad air was believed to cause the spread of infectious diseases. The causes of epidemics were, from ancient times, thought to reflect shifting weather conditions, natural disasters, or punishment for bad habits (Joutsivuo 2005:180; Jenner 2011:345). Diseases were thought to be generated by human actions in closed spaces or brought from other places just by traveling on the wind. Disease could be conveyed by infected people, objects, and by ingesting foul-smelling air emanating from within the earth or pestiferous zones (Riley 1987; Thorsheim 2006:10; Reinarz 2014:159). Inhaling fetid air was considered akin to poison to the brain, while the fumes were directly absorbed into the body (Palmer 1993:63-65; Jenner 2011:345).

\section{Smells and Scents}

The postmedieval world was characterized by a universe of unpleasant odors. The most commonplace sources of unpleasant odors were personal hygiene, people working in particular industries (fishing, tanning), household wastes, and animals and their waste (Pawlowska 2014). Even though these everyday smells were considered foul and unhealthy, they were long tolerated as a natural part of the cycle of life. At the turn of the 19th century, though, the real war against smells was reflected in new efforts to improve drainage, sewage, sanitation, and garbage systems (Riley 1987:13; Palmer 1993; Classen et al. 1994; Jenner 2011:340).

Different individuals sense odors differently. The sense of smell has been considered "unclear" compared other senses. For example, sight and hearing are understood as senses that produce sensations that are more easily described (Palmer 1993:61). Because of this, archaeologies of the senses have primarily focused on vision, sound, and tactility, and minimized other sensorial modalities (Hamilakis 2013:95). In the classic book on smells by Constance Classen, David Howes, and Anthony Synnott (Classen et al. 1994), the social and cultural roles of smell are highlighted and discussed in historical, anthropological, and sociological perspectives: "It smells like ...', we have to say when 
Fig. 1 Map showing the locations of towns and areas discussed in this article. (Drawing by K. Vajanto, 2018.)

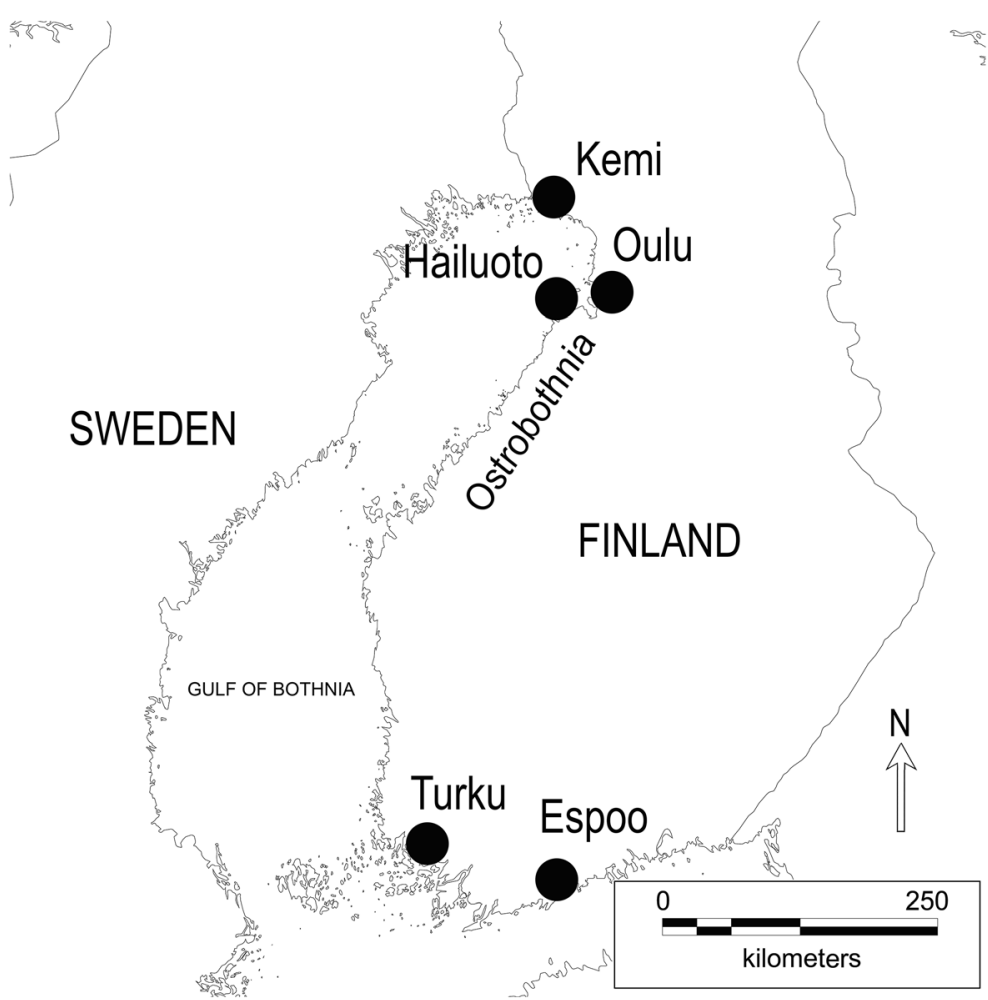

describing an odour, groping to express our olfactory experience by means of metaphors" (Classen et al. 1994:3). The smell of death is an exception. When a person has experienced the smell of a rotting human body, it is clearly articulated and remembered. According to 16th-century scholars, the smell was sensed in the brain, and it had a materialized form, since "the smell was considered a smoky vapor arising from the substance of a thing" (Anglicus, quoted in Palmer [1993:62-63]). These ideas later had a strong impact on how the smell of decomposing flesh was experienced in churches.

During the 18th century the Swedish botanist Carl von Linné categorized odors in the same way he classified natural species, placing odors within nature in the same manner as plants and animals (Ruoff 2003:14). As odors had a natural place in nature and people's lives, smells, and especially incense, have been central in the world of ritual ever since the civilizations of ancient Babylonia and Egypt. Some plants symbolized or represented deities, and their smells and the smoke generated by their burning were believed to unite humanity and the gods. Incense acts as a kind of communicative mechanism that was believed to cleanse, improve, block, or engage a connection with God. Pleasant smells and clouds of smoke helped the deceased get to heaven. Early Christianity abandoned the use of incense, but the church eventually incorporated incense and the burning of plants into ritual practices in the 13th century (Reinarz 2014:43).

Because pleasant odors reflected a healthy environment and relationship with God, good smells were used to cover the foul ones, the smells of sin. As early as in ancient Mesopotamia, social disarray was associated with bad odors and the devil's powers (Reinarz 2014:25,44). Premodern Christianity was also based on olfactory theology, but the distinction between good and bad smells was not always clear. Some pleasant smells indicated sin or a possible fall into the state of sin, so the difference between heavenly and erotic smells could be small (Reinarz 2014:44,49-50). Nevertheless, the tolerance of bad smells could indicate someone's devoted and godly soul. To parishioners, the bad smells in churches were also a warning and a reminder of death and hell. According to pre-Christian heathen beliefs in Finland, the deceased lived in the kingdom of the dead, Tuonela, and acted as the guardians of the living community (Lehikoinen 2011:267). The Lutheran state Church of Sweden interpreted these guardians as a dangerous group against which the parish needed 
the church's protection. This way the church frightened the parishes into remaining devoted to God and the church (Lehikoinen 2011:262-268).

According to Jenner (2011:346), recent scholars have paid more attention not only to the fact that odors mattered more in past societies, but to the cultural and social impacts of the odors. For instance, how did different odors define certain groups of people, their actions and traditions, and the material culture surrounding them? Sensorial experiences also create memories. According to Yannis Hamilakis (2013:118), a sensorial perception is never a prereflective, pristine experience. Instead, the work of memory is based on senses, and the senses rely on the materiality and the physicality of the world. Senses can be seen as materiality's way of prompting both memory and forgetting alike (Cole 1998:6). Since a smell can be seen as a cultural phenomenon (Reinarz 2014), the sensorial experience linking the impulses from different senses is created by traditions. Hamilakis (2013:75-80) outlines the example of the experience of the celebration of the eucharist in the church, which is a corporeal experience connecting multisensory elements, such as objects, sounds, and smells. These sensed experiences help to create memories and associations.

\section{The Town of Oulu and Northern Finland during the Early Modern Period}

The archaeological material in this article comes mainly from the 18th-century town of Oulu (Fig. 1) and comparative research from rural Finnish and Swedish towns. Until the start of the 19th century, Finland formed the eastern part of the Swedish kingdom. During the 16th century, Sweden's ruler Gustav Vasa concentrated trading in towns where taxes and customs could easily be collected. Earlier marketplaces had been located exclusively in the shore areas of the Gulf of Bothnia, and Oulu had gained a status as an official trading place in 1531 (Vahtola 1991:145-148,210). In 1605 the town of Oulu became the first town to be established along the northeastern shores of the Gulf of Bothnia. The town was founded on the mainland just opposite an island on which a castle had been built in the 1590s (Virkkunen 1953:88).

The first town was medieval in style, formed around a curved main street. The important features, such as the harbor, market area, and church, were along this street
(Fig. 2). The town of Oulu received a new church in the early 1610s, and since then the church has remained on the same plot. The first church was an approximately 30 $\mathrm{m}$ long wooden structure, and it was lengthened during a 1682-1686 renovation (Virkkunen 1953:467-473; Snellman 2000:55; Kallio-Seppä 2013).

Today the center of Oulu remains in the same area in which the original town was established, which has led to many archaeological excavation projects there since the 1970s. Since the town was located on the seashore and a river estuary, and the town was formed around a ditch that broke the town into two halves, the physical structure of the town contained many smelly and otherwise unpleasant wet areas and ponds that affected the ways the town space was later developed. Archaeology has revealed that residents coped with the damp environmental conditions by using layers of wood to fill wet areas and cover wet street surfaces (Kallio-Seppä 2013).

Archaeology has revealed changes in the street plan and its smellscape during the 18th century. Administratively, the town of Oulu underwent major changes and developments. At the end of the century, the town received a nomination to be the capital of the county, after which the county governor settled in the town. In addition, the population rose during the late 18th century. The rapid growth started after 1765 , when the town was granted free foreign-trade rights. In the middle of the 18th century, the number of residents was around 1,900 , but in 1785 the population had already expanded to more than 3,200 (Vahtola 1991:355-356).

\section{Miasma in Urban Surroundings: Wastes and Wet Areas}

In the Middle Ages towns represented civilization and Eden, since the built environment was seen as the opposite of untamed wilderness. However, by the beginning of the early modern period the city had come to represent sin and sickness (Joutsivuo 2005:190-196). The ideas of miasma were strongly linked to urbanization and the drainage, sewage, sanitation, and garbage problems that elevated mortality rates in the most densely inhabited areas (Riley 1987:13; Palmer 1993; M. Susser and E. Susser 1996:668-669; Corburn 2004:541-542). The more organic material a place contained and the greater the temperature, the more miasmas were thought to be produced (Thorsheim 2006:11). 


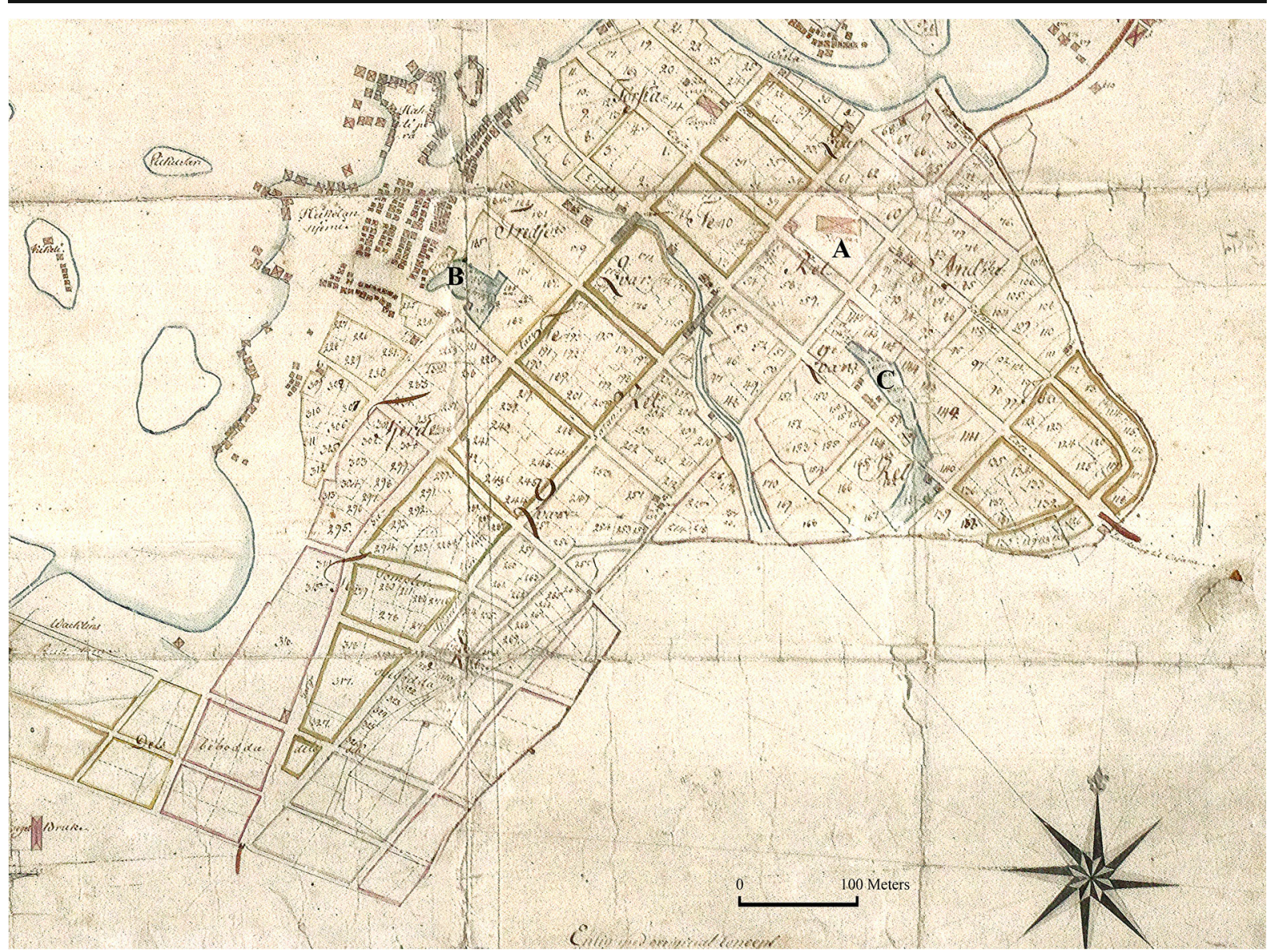

Fig. 2 The map of the town of Oulu from the year 1763 by Mårten Hackzell, showing the wet areas inside the town borders and locations mentioned in the text: $(A)$ Oulu church, $(B)$ the Hjärpenlampi, and $(C)$ the School Pond. The blocks and lots assumed their regular shape during the latter half of the 17th century (Hackzell 1763). (Map courtesy of the Northern Ostrobothnia Museum, Oulu, Finland.)
During the 18th century, observers debated which was the healthiest living environment and contemplated where the healthiest people lived (Joutsivuo 2005:183). Sweden was trying to increase its population in the 18th century, and the problems in the major European industrial cities had raised the impression that concentrated populations caused mortality and pathological diseases. London and Paris, for example, suffered severely from sanitation problems. The miasmatic steams in such cities were believed to be directly caused by standing water, swamps, and rotting animal and plant wastes (Vuorinen 2010:227-228; Reinarz 2014:180-181). Attempts to keep the streets of Swedish towns clean and minimize wet areas often came during the spread of epidemics, such as plagues in 1710-1711 and the 1770s (Suolahti 1917:100; Classen et al. 1994:57).

The municipal regulations related to waste management were often ineffective. The orders left too much responsibility to private residents, who did not cart off their wastes and, as a result, suffered from unpleasant odors and dirty surroundings (Classen et al. 1994:57). In northern Finnish towns waste was often carted to pits located on house lots (Mäntylä 1971:153; Kallio-Seppä 2013; Helamaa 2015). In Oulu, wet areas surrounded the church during the 17th century. These wet areas had been a subject of residents' complaints in the middle of the 17 th century, and in the 1680 s the local bourgeoisie were ordered to make the area dry so that "the town residents could enter the church with dry shoes." These areas just outside the churchyard border were used as 
common waste dumps and were dried by introducing sand and wood, the latter ranging from branches to logs to wood chips (Virkkunen 1953:126-127; Kallio-Seppä 2013:82).

Contemporary administrative descriptions of Oulu's 18th-century appearance tend to romanticize certain problems, repeat earlier descriptions, or come from writers who never even visited the town. Nevertheless, the 1737 doctoral thesis of historian Johannes Snellmann described the features of the town of Oulu and examined wetness in the northern part of the town:

In the northern part of the town there is a boggy place that out-of-town guests and local residents call the dirt street. Because this area has been damp and every now and then it gets really wet due to flooding, there have been ditches dug and drains and water tanks built. After this, the place is almost dry, even in parts where frogs used to croak in muddy grass. ... The area was like ancient Venice or how our Stockholm is nowadays, with many tower structures and rocks and foundations built in the water on wooden piles [translation by authors]. (Snellmann 2000:36)

After explaining what had been done to avoid wetness, however, Snellmann discounted the negative effects of miasma, noting that "even though those that have grown up in cultivated circumstances and smelled beautiful scents think that it is harmful to breathe in these moist and boggy steams from the air, it is widely known that the health of this area's residents has never suffered from them [translation by authors]" (Snellmann 2000:36).

Until the latter half of the 19th century, there were two larger ponds inside the town area in Oulu: the Hjärpenlampi and the School Pond (Fig. 2). Archaeological excavations in the Hjärpenlampi have revealed that the fringes were part of the surrounding house lots, with granary and quay constructions built partly in the water during the latter half of the 17 th century. These structures had strong foundations built of thick logs that were laid below the water level (Fig. 3). During the 17th and 18th centuries, the fringes of the pond were used as extensions of the private lots. Residents had direct access to the sea from the pond through a narrow ditch. However, this connection was disappearing during the 18 th century as the water level of the pond became lower. At the same time, written documents reveal complaints about the odors the ponds were producing. These complaints were made by the residents, but also by county governor Johan Carpelan, who proposed in the 1780s that the School Pond on the eastern side of the town should be filled up so "that it would stop troubling the Oulu residents with the terrible smell that is spreading from it, especially during the summer months." Stagnant water in shrinking ponds can easily produce unpleasant smells that would, at least by modern-day standards, bother the inhabitants of the closest homes (Halila 1953:81; Kallio-Seppä 2013:123-131).

Microfossil analyses of samples taken from the layers of the Hjärpenlampi have revealed the effects of human actions in the area, especially from the 1720 s onward, as a more urban ecology emerged. Pollen and diatom analyses indicate that human action did not destroy the pond before it was filled. Just before the filling it contained diatom species that indicate some degree of eutrophication, and that the oxygen content had dropped, but the $\mathrm{pH}$ value was near neutral. This indicates that the smells coming from the pond were not so severe that they would have compelled the residents to eliminate the pond (Heikkilä 2011). What then can be seen as the primary reason for filling up the pond, if odor was not the driving factor for change? In 1761 the Hjärpenlampi was sold to a burgher named Abraham Strömmer who agreed to fill it and build on it. Filling was done in cooperation with several lot owners. According to archaeological material and dendrochronological dating the filling was carried out during the 1770 s or $1780 \mathrm{~s}$ (Halila 1953:81; Kallio-Seppä 2013:129).

\section{The Tradition of Church Burials and Sweet-Scented Plants}

Several social and cultural factors affected 17 th- and 18th-century Swedish burial. Traditions, norms, and various regulations by secular authorities and the Swedish ruler influenced how the deceased were prepared for their graves, and when, how, and where they were buried. Burial gave the deceased a resting place according to their class, but it also highlighted the social class of the bereaved. The desire and tradition to be buried under the church floors were strong. According to superstition, the closer the deceased was buried to the remains of martyrs and the altar, the better the souls felt. Because the church received a payment for these burials, 


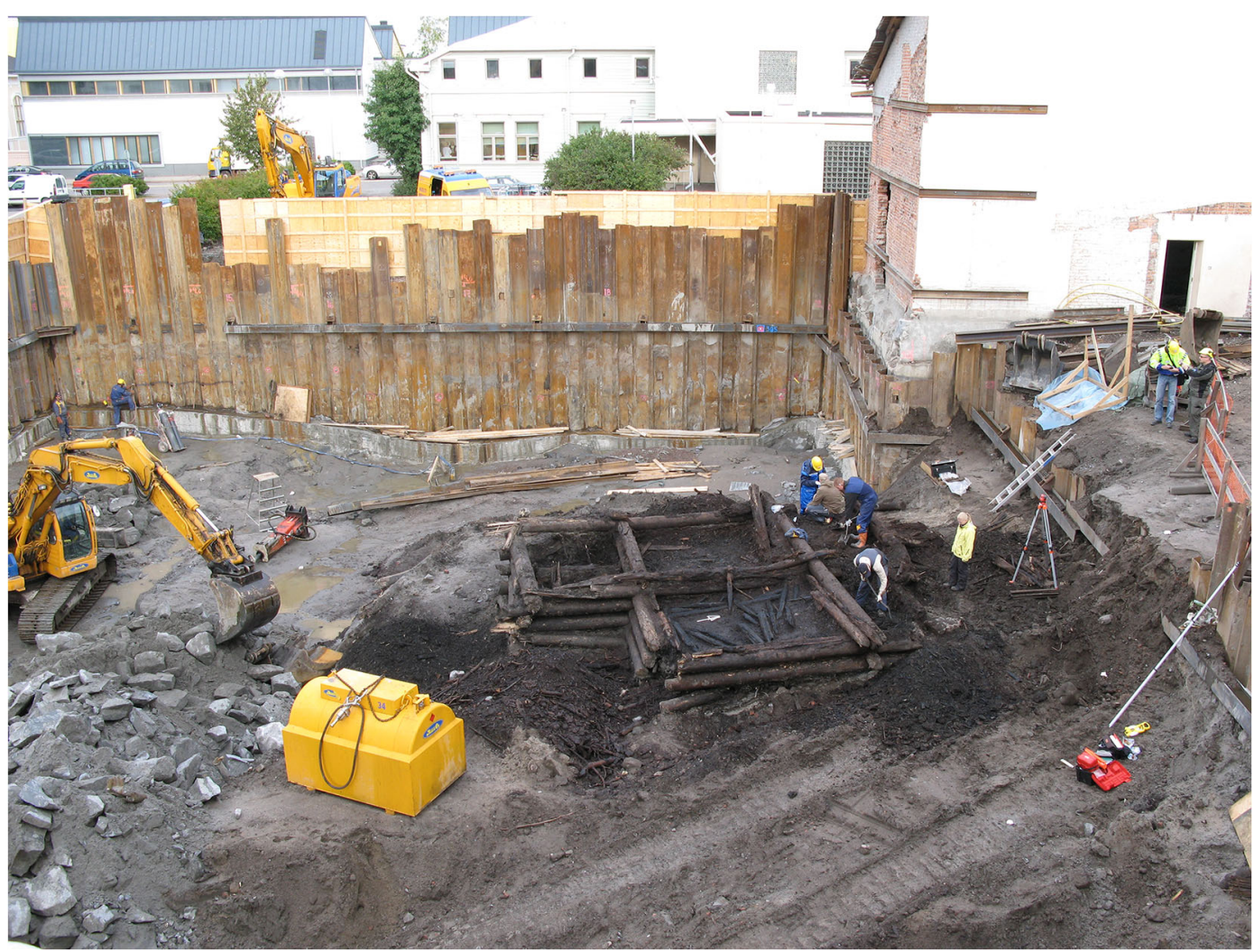

Fig. 3 Wooden foundations built on the pond Hjärpenlampi. (Photo by M. Hyttinen, Finnish Heritage Agency, 2008.)

this substantial economic benefit has been thought to be a reason for the parishes to continue this burial custom, especially during the 17th and the early 18th centuries (Warelius 1861:16; Korhonen 1929:303-304,312; Pylkkänen 1954:41; Nordberg 1970:490-491; Virrankoski 1973:676; Laasonen 1991:326; Paavola 1998:31-34,37,40).

In practice, the wealth of the deceased, but also environmental conditions and changing climate during different seasons, affected where the final resting place of the deceased was to be (Hellemaa et al. 1986). This tradition ended gradually in individual parishes beginning in the latter half of the 18th century. The definitive order to cease church burials and close the old ones under the floors was given in an 1822 imperial decree (Kejserliga Senatens för Finland 1826:70-71).

Since certain smells had significance, the olfactory world was to be actively influenced. During the medieval period, the most important element of a garden was its fragrances, not the rich and spectacular bloom and colors of the plants that are the key features of the modern garden (Ruoff 2003:13). For herbs, important in medical and religious connections, a strong scent is a characteristic feature. The scent was magnified by using bundled plants as "nose herbs" and also by scattering them on the floor. They were used especially for festivities or church ceremonies, but more often in upper-class and elite households. Among other things, bunches of southernwood (Artemisia abrotanum), which was fashionable in England in the 18th century, were used in churches in Kemi (northern Finland). The upper classes scattered plants on the floors of their living quarters. For example, crushed calamus (Acorus calamus) was often used in 16th-century England, and its use continued in the 19th century in Germany. Queen Elizabeth I in England used meadowsweet (Filipendula ulmaria) leaves and stems as floor herbs. Remnants of these practices were still apparent in 19th-century Finland, where scraped spruce twigs and juniper needles were sprinkled on floors on Sundays (Ruoff 2003:163,179177,180; Piippo 2008:206).

The archaeological excavations in the Oulu Cathedral graveyard have revealed individuals buried both inside and outside the church building, dating from the 17th century to the 1770s (Kehusmaa 1997; Sarkkinen and Kehusmaa 2002). No flowering organic decorative 
material was recognized inside the graves. What survived were mainly plant remains - hay, spruce, birchindicating pillows, mattresses, and covers. One burial contained alder (Alnus sp.) and birch (Betula sp.) twigs underneath the skull (Kehusmaa 1997; Piippo 2008:457,462). Spruce, juniper, and birch have strong odors to cover any stench, so they also had a disinfecting effect.

Ostrobothnian macrofossil analyses and folklore studies reflect the cultivation and use of "nose herbs," that is, "church bouquets." Marjoram (Origanum majorana), oregano (Origanum vulgare), wormwood (Artemisia abrotanum), thyme (Thymus officinalis), and mint species (Mentha spp.) were helpful herbs that masked bad odors (Ruoff 2003:16,179; Piippo 2008:160; Tranberg 2018). Also, sage (Salvia officinalis), lemon balm (Melissa officinalis), hyssop (Hyssopus officinalis), lavender (Lavandula spp.), and valerian (Valeriana officinalis) were commonly used in the Oulu townscape and church services (Salmi et al. 2014; Tranberg 2018). These herbs were used mainly as nose herbs, but, due to their scent, they were also believed to have an impact on illnesses.

The fragrance, however, did not last long and could not cover the smell of a decomposing body. Nevertheless, flowers with a heavenly odor were placed on the casket to help the deceased reach a suitable space to join the Creator. Along with birch and hay, Norway spruce is a common grave plant found in coffins under the churches of Ostrobothnia (Paavola 1988, 1995) (Fig. 4). As evergreens, the spruce branches in a coffin could symbolize eternal life, but their use is strongly associated with their smell and believed ability to dispel diseases (Ruoff 2003:179,186). The smell of the spruce and smoke was believed to act as a disinfectant against airborne disease, and spruce has been commonly used throughout Sweden (Nyberg 2010:25-26). It is noteworthy that often the grave plants are associated with a soothing or sedative effect, as, for example, valerian and hops were considered soothing, not just concealing, odors. The road to heaven was made easier with certain plants (Lagerås 2016:15-28).

Many plants were used as protection against an evil spirit. In addition to people's sinful behaviors, evil spirits were believed to be guilty of causing illnesses because they infected the air. This infection was confirmed by bad smells. Medicines against diseases were called air fresheners, purifiers, or healers. Several plants were assumed to have a disinfectant effect and the power to kill bacteria. These bacteria killers, thyme, anise (Pimpinella anisum), and ferula (Ferula spp.), were already in use in Egyptian embalming methods. In times of epidemic, such as cholera and bubonic plague, Finns were advised to use certain plants as protection, including lovage (Levisticum officinale), basil (Ocimum basilicum), rue (Ruta graveolens), verbena, lavender, laurel, rosemary, juniper, thyme, and marjoram (Ruoff 2003; Piippo 2008).

Spruce - in addition to savin juniper (Juniperus sabina) — was also believed to promote health. Since bad odors were associated with illness, a strong smell, like spruce, was aimed at fighting against diseases and vermin. Martin Luther said that evil spirits could cause the plague by poisoning the air (Reinarz 2014:43), and Norway spruce has been the most common plant used in the fight against epidemics in Oulu. In 1831, residents were ordered to spread twigs of spruce on floors during a cholera epidemic, and the same method was continued later in smallpox epidemics (Ruoff 2003:179). Herb plants also worked as pesticides. Marjoram (Origanum majorana), oregano (Origanum vulgare), and thyme (Thymus vulgaris) prevented diseases (Ruoff 2003:16,52,176-179,186,195). The common element among all these plants is a strong scent (Fig. 5).

\section{Complaints and Orders Concerning the Smell of Decomposing Flesh in Churches}

Ideally, the services in churches were not meant to be pleasant experiences for the members of the parishes. The smell of death created an olfactory image of the place that reminded churchgoers of their mortality and the brevity of life. The notion of "memento mori"remember that you must die — was materialized by the sense of smell.

The way the deceased were laid under the church floor affected the amount of smell the bodies created. According to the 1686 Church Law, when interred inside the church the coffins had to be buried ca. $178 \mathrm{~cm}(5.85 \mathrm{ft}$.) deep and covered with soil (Hellemaa et al. 1986:18.8.32). The orders were not often followed, since the coffins were buried inside burial chambers that had wooden roofs. This resulted in many complaints, since the chambers were not filled or covered with soil (Virrankoski 1973:678).

In Finland, the fetid odors rising through the church floorboards were mentioned in many instances in parish 


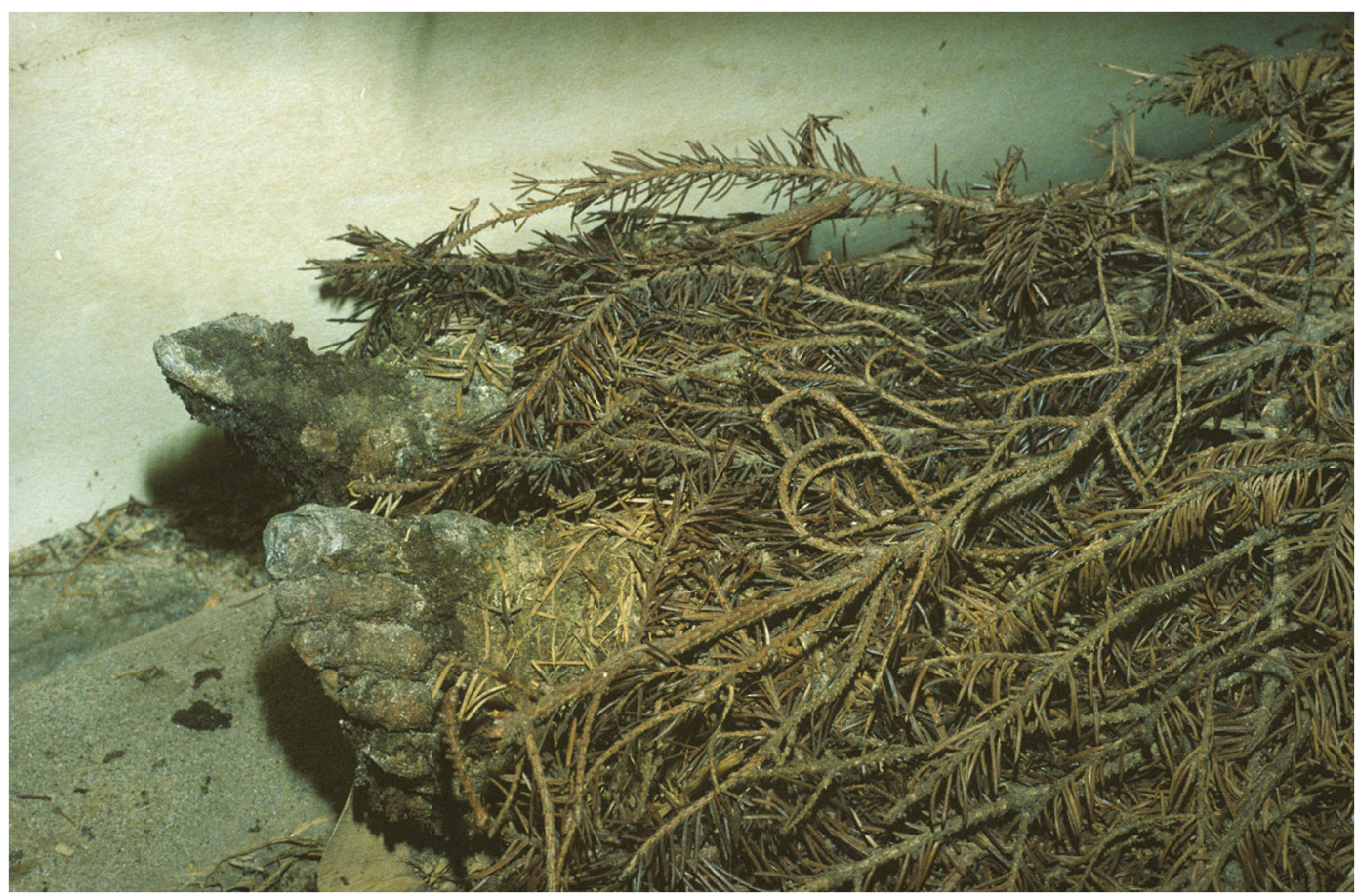

Fig. 4 Toes peeking out from beneath Norway spruce branches. (Photo by K. Paavola, 1996.)

archives and in orders coming from the Swedish Crown or bishops. According to Paavola (1998:39-40), the first clear signs of criticism were from the middle of the 17 th century and came from secular authorities, the ruling hierarchy of the church, and the regular clergy. The criticism focused on two major things. First, population growth and the spread of the burial custom among the lower social classes led to a lack of space under the floors. This lack of space in churches was cited in 1642 on the initiative of the clergy in discussions in the Swedish parliament and privy council (Bergh 1902:82,431). The second reason for criticism was the foul odors that the church burials were spreading.

In 17th-century references the putrid smell was often highlighted. Written and archival sources tell about burying the deceased in chambers that were not covered with soil, but closed with a door or a lid that might then, possibly, be covered by birch bark. During that time the graves were also often dug to shallow depths (Warelius 1861:14; Virrankoski 1973:678; Vahtola 1991:276). This inadequate covering was one reason for foul odors in the church air that sometimes caused churchgoers to vomit and clergymen to postpone their meetings during the warmest summer months (Nordberg 1970:490-491; Nyberg 2010:26). Officials tried to prevent the inadequate covering of the coffins by warning parishioners that they would lose their right to church burial if they did not obey the order (Paavola 1998:112). In Oulu, a fine of 1 mark had to be paid to the church if human bones or rotten wood planks were found visible in the church or in the churchyard (Virkkunen 1953:508). Archaeological excavations in Oulu have revealed numerous burial chambers and individual burials in the area of the old church. Since the church had been built on a slight slope, the original surface of the ground was not even. Soil had also been taken away and brought to the site over centuries, but in some parts of the churchyard the upper surface of the burial chambers was approximately $1-1.5 \mathrm{~m}$ below the contemporary surface (Sarkkinen and Kehusmaa 2002).

During the 18th century, the bad smell during the spring and summer was still one of the main arguments in parish and provost meetings for ceasing or at least cutting back on the number of church burials (Forsman 1899:207-208; Pylkkänen 1954:41). The arguments were based on the idea of harmful toxic evaporations and the fear of the spread of contagious diseases, such as the plague, slowly prevailed. Also, the idea raised its head that preventing the burials inside the town areas would diminish the diseases caused by the poisonous stench (Baelter 1762:784). In 1710 the first order against burial of the plague dead in the churchyards or churches 
Fig. 5 The herb Artemisia absinthium (absinthe or wormwood) from the garden. (Photo by A. Tranberg, 2017.) was given (Baelter 1762:78; Forsman 1899:206). In 1711 Bishop Jesper Swedberg sent a letter to the priests in the Skara Diocese in Sweden and scolded them for being careless about the ban preventing the church and churchyard burials of plague corpses. The justification was that the graves were emitting a toxic stench during spring and summer, and it was argued that it was as honorable and joyful for the deceased to be buried in a graveyard outside the town borders as inside the church or the churchyard around the church (Baelter 1762:781784; Korhonen 1929:324; Paavola 1998:40). Forty years later the parishioners were reminded that all people are equal when they die, and for this reason the burial place in the churchyard would be as precious as that in the church (Pylkkänen 1954:41). Such orders are known to have been ignored, though. For example, in the town of Tornio in 1711, five people who died of the plague were carried to a local church to be buried (Mäntylä 1971:223).

Odor affected how the church space was used. For example, in some churches the parishioners wanted to keep the church doors open during the services, or the services had to be held outside. Of all the churchgoers, the unhealthy smell of death was often considered especially harmful to pregnant parishioners (Hydenius 1765:15; Forsman 1899:207-208; Keränen 1977:188).

In 1772 Field Marshal August Ehrensvärd wrote a letter to Finland's county governors describing four means to prevent epidemics spreading through the air. One of these was to discontinue the habit of burying the deceased inside the churches. Also, an order was given that all diseased bodies should be buried in graveyards outside the towns, thoroughly covered and the soil compacted (Hjelt 1911:77,150,153). In 1779 the 
representatives of the clergy again requested that the Swedish king abandon the unhealthy tradition of under-floor church burials based on the lack of space, odor, and health risks, arguing that the churches were meant for services, not to serve as burial places (Wilskman 1782:961; Nordberg 1970:490-491; Paavola 1998:42). Each parish was allowed to make an individual decision about when it wanted to ban church burials (Lempiäinen 1990:11), but in 1786 the Swedish king reminded his subjects about the drawbacks of church burials and strongly recommended graveyards located away from the churches (Modée 1803:349-351).

\section{Under the Church Floors to Graveyards outside the Town Borders}

To be buried inside the church of Oulu was still rare from 1630 to 1670 , when only about 50 people were buried in the church. However, the most intense period of church burials was from 1720 to 1740 . In Oulu the tradition was consistently popular after 1722 because of population growth, and even the lack of space inside the church did not prevent the burials (Paavola 1998:102,110). The estimated number of individuals buried, until the end of the practice in 1769, is between 2,040 and 2,050, and the theoretical space for each coffin was only $0.2 \mathrm{~m}^{2}$. Statistically, the bourgeoisie was the largest group of town residents buried under the floor of the Oulu church. Also among the buried were clergy, officers, and soldiers (Paavola 1998:91,109-110,209-215,254-257).

Other Europeans had begun to abandon church-floor burials by the middle of the 18th century (Jenner 2005). The first documented examples are from England and France. In England, the criticism of church-floor burials began in the $1720 \mathrm{~s}$, when a London curate, Thomas Lewis, published a pamphlet, Seasonable Considerations on the Indecent and Dangerous Custom of Burying in Churches and Church-Yards. A published account of the death of three gravediggers exposed to malign fumes of rotten corpses in a church in Montpellier, France, in 1744 was also widely disseminated (Jenner 2005). During the 17th century, John Arbuthnot's An Essay Concerning the Effects of Air on Human Bodies mentioned church burials. However, this essay was not published until 1751 , by which time the ideas of transmitting diseased through air had become more common (Arbuthnot 1751:18,209).

The public discussion of the tradition started in Finnish newspapers in the 1770s (Suolahti 1917:23-25). In 1773, a short text in Tidningar Utgifne Af et Sällskap I A bo (1773) warned that the habit was a threat to the lives and the health of the living churchgoers who were forced to attend services in harmful surroundings containing toxic gases. In 1777 the same newspaper contained a larger report on the malign habit by citing the Montpellier text that had been published in France 30 years earlier (Tidningar Utgifne Af et Sällskap I Åbo 1777). Both of the newspaper articles refer to incidents in which gravediggers had become ill and died. Examples were used to demonstrate that the decomposing and swollen corpses contaminated the air.

Oulu was the first Finnish parish that established a graveyard separate from the church and outside the town borders. In 1780 the vestry and the church council asked for permission to establish it, and permission was granted the same year by the county governor (Onnela 1982:16-17; Palola 2000:118; Kallio-Seppä 2013:70). Before this, some separate cemeteries had been established for those who had died of plague in Finland, but those were not used for other burials (Rinne and Meinander 1912:49-50; Nikander 1945:279-282).

Since the 1750s, there had been discussions about building a new and larger stone church to replace the old and dangerously deteriorated wooden building and to better meet the demand of the growing parish. After long disputes, the old church was pulled down in 1769 or 1770. The new church, dedicated to Queen Sofia Magdalena, opened in 1777 (Halila 1953:550-556; Vahtola 1991:473-475). The last payment, 2 thalers and 8 öres, for a burial in the old Oulu church was received in October 1769 for burying the child of Jakob Vaikko. No one was buried in the new Sofia Magdalena Church while it was under construction. There is no evidence for burials under the new church floor after its construction was completed in 1777 (Paavola 1998).

In Oulu the transition to a new graveyard did not happen without resistance. The support for continuing the old burial rituals and traditions remained strong in some quarters, especially among the bourgeoisie who had possessed burial chambers under the old church and had invested money in chambers that could no longer be used. Some of the bourgeoisie wanted to build new chambers in the old churchyard to replace the old ones under the church floor. This proposal was rejected, but a 
private, joint burial chamber for a couple of merchants was built in the new graveyard instead (Halila 1953:535; Pylkkänen 1954:41; Nordberg 1970:490-491; Hautala 1975:356-357). Some of the wealthiest residents also purchased their final resting places under the floors of neighboring parish churches where church burials had not yet been abolished (Onnela 1982:17; Paavola 1998:117). One concession from the church was that in the new church a sort of "transfer burial site" was created under the church floor, where the deceased were laid during the burial ceremony before being transferred to their final burial location in the graveyard (Paavola 1998:99-100,261).

The tradition of church burials in Oulu ended when the new church was completed in 1777 (Paavola 1998:100). This was not a matter of principle or a voluntary change, but more of a chance to change traditions when the holy place was changing. For example, the vicar was against opening the floor of the new church (Karvosenoja 1995:51). At the same time, the problem of foul odors of rotting corpses began to be viewed as the problem of neighboring rural parishes that were greedy enough to welcome payments for burying the bourgeoisie of the town within their churches. Also, their actions represented unwillingness to relinquish the old traditions.

The effort to eliminate bad odors in public spaces and under church floors was driven by centralized power, such as clergy and county governors. During the last two decades of the 19th century, scholars finally understood more about bacteriology and realized that noxious odors were not themselves particularly hazardous. Slowly, the idea of bad smells spreading disease was replaced by more modern concepts of epidemiology (Jenner 2011:346).

\section{Conclusions: The Late Eighteenth-Century Cleaning of the Causes of Smell}

In 18th-century Oulu two types of olfactory sources stand out in written records and in the archaeological material: the odor of decomposing flesh in church and the scent of wet ponds inside the town borders. The causes of the odors were related to social traditions and habits, as well as natural conditions. Human agency had a significant role shaping both traditions and conditions, and both of the sources of odor were eradicated by the building of the new church and graveyard in the 1770 s and the filling of the larger ponds in the 1770s and 1780s.

Both of these changes occurred during a period in which the town had grown substantially larger and wealthier after receiving the right to practice foreign trade in 1765 . During the 1770 s, the county governor moved to Oulu, which quickly resulted in the development of the town. These improvements in trade and governance, together with rapid population growth, affected the townscape. The governors of Oulu wanted to change the appearance of the town to a regularly organized space and create more building space by filling up the ponds and laying out whole and regularly sized blocks and lots. A stone building right next to the Hjärpenlampi was bought as a governor's residence in the $1770 \mathrm{~s}$, and the filling of the pond can be seen as a way to take control over nature. Filling and draining of larger swamps and lakes was also common in the rural areas during the same period (Enbuske 2010:139).

It seems that the 1710's plague raised the question of hygiene, which motivated residents to place graveyards outside the churches and towns. During the 18th century, the aesthetic and practical reasons for establishing new burial practices were discussed. The clergy became more aware of the issues related to health and promoted the new attitudes (Laasonen 1991:326; Kallioinen 2009).

According to Hamilakis $(2013: 115,196)$, when a sensorial approach toward smells is taken, corporeality should be discussed, not just odors related to bodies:

[T]he senses are not about the mechanics of the body and about sensorial organs. Despite their organic components, they supersede the organic, and their primary role is to produce affectivity, to move and touch us, to connect us with other bodies and things, to facilitate the flow of substances, affects, memories, and ideas. As modes of being and relating to the world, the senses have been culturally produced.

The experience of smells and their materiality is important. Odors, either pleasant or foul, bring about feelings, actions, and associations in individuals, and socially between groups of people. As Connerton (2009:33) has argued, a sense of place is formed as a 
complex interplay of visual, auditory, and olfactory memories. In addition, the sensory engagement with the material world helps to create bodily memories (Cole 1998:6). According to Elmgren (1847:205-206), during the first half of the 19th century older people used to tell stories to the younger generations about how they sat in the church pews suffering from the stench. In this way, the smellscape of the churches stayed in social memory even though the burial tradition had been out of use for a while.

Probably the wet areas and complaints about their smells can be seen as reflections of miasmatic ideas. It was not considered appropriate to address directly that they produced harmful mists that were considered to be unhealthy, but it was more acceptable to talk about smells instead. The fear of miasmas in wet areas was strong, but microfossil analyses suggest that the wet areas did not produce especially unpleasant smells. Complaining about odors was an expression of a shared experience of unpleasant smells that was a collective issue for the residents. Wet areas and their subsequent incorporation into the public streetscape and house lots affected how the residents understood and experienced urban space. Oulu was also much smaller than the European cities that suffered from bad odors. It may also be that it was thought that a town was only considered to be a "real city" if it could complain about a bad smell.

In Oulu, the putrid smell in church was not the only reason to prevent church burials, but it can be seen as one of the social subplots in the issue. In death, all people can be said to be equal. Regardless of social class or background, all go through putrefaction, creating foul odors. But, when it was the question of church burials, it was long a privilege of the wealthier residents. The smells were often connected with lower social classes. The ideal was that the representatives of the upper classes did not create unpleasant odors (Howes 2006:168; Reinarz 2014). However, in churches it was the relatives and the people from the same social classes that created the smells. The custom became more popular among other town residents too, which led to the church floor becoming full. The lack of space in Oulu and the church's physical deterioration became key reasons to change under-floor burial practices. The new church building and its floor were intended to be kept intact and clean from putrid smells. During the Age of Enlightenment, according to Korhonen (1929:323$324)$, it took a very long time to end under-floor church burials, even though it must have been unpleasant for the parishioners and the clergy. In Finland, as in other countries, the habit was gradually discontinued quite independently in each parish, although orders were given from the upper levels of the church hierarchy. Changing burial customs reflected major shifts in mentalities that were preceded by strong resistance from the locals.

Like many other attitudes, the attitude toward the olfactory world was slowly changing, and its change was influenced by many factors. Although it can be said that bad odors were a sign of many bad things, such as sin, it can also be said that they were also a good thing. The church used bad smells as a deterrent and a reminder of death. The pious endured the bad odors, but the weak did not endure unappealing fragrances. Good smells were a direct link to the joys of heaven and a sign of virtue. Even though a late relative may cause unpleasant smells under the floor of the church, getting a church burial was desirable, and the privilege was something one might want to keep. Behind the smells there was a strongly rooted symbolic system that was difficult to transform.

The 18th-century town of Oulu was a small, northern Swedish town, but it suffered the same problems related to cleanliness, rapid rise of population, and miasmatic stench as did larger European cities. The changes to the smellscape in Oulu were made according to the ideas and examples coming from these larger cities and the ideals of the Age of Enlightenment. The 18th-century lowering of olfactory tolerance thus brought about major changes in burial customs and the physical appearance of the town, creating, in many ways, a more regular and cleaner town. The church space was regularized by cleansing it of the miasmatic smells. The foul odor was no longer connected to holy services. Filling of the wet ponds, on the other hand, created more town space that could be effectively used when new land for blocks and lots was created inside the town borders.

Acknowledgments: We thank the Kone Foundation and the Emil Aaltonen Foundation for financial support, Markku Kuorilehto for advice, and the Church, Space and Memory team for support during the writing process.

Funding Open access funding provided by University of Oulu including Oulu University Hospital.

\section{Compliance with ethical standards}

Conflict of Interest Statement On behalf of all the authors, the corresponding author states that there is no conflict of interest. 
Open Access This article is licensed under a Creative Commons Attribution 4.0 International License, which permits use, sharing, adaptation, distribution and reproduction in any medium or format, as long as you give appropriate credit to the original author(s) and the source, provide a link to the Creative Commons licence, and indicate if changes were made. The images or other third party material in this article are included in the article's Creative Commons licence, unless indicated otherwise in a credit line to the material. If material is not included in the article's Creative Commons licence and your intended use is not permitted by statutory regulation or exceeds the permitted use, you will need to obtain permission directly from the copyright holder. To view a copy of this licence, visit http://creativecommons.org/licenses/by/4.0/.

\section{References}

Arbuthnot, John

1751 An Essay Concerning the Effects of Air on Human Bodies. J. and R. Tonson and S. Draper, London, UK.

Baelter, Sven

1762 Historiska Anmärkningar om KyrckoSeremonierna, Så väl Wid den offentliga Gudstjensten, Som Andra tilfällen hos de första Christna, Och $i$ Swea Rike; I synnerhet Efter Reformationen til närwarande tid (Historical notes on the church ceremonies, public divine services, and other ceremonies of the first Christians in the Kingdom of Sweden; in particular after the Reformation until the present day). Peter Hesselberg, Stockholm, Sweden.

Bergh, Severin (editor)

1902 Svenska riksrådets protokoll med understöd af statsmedel $i$ tryck utgifvet af Kongl. Riksarkivet genom Severin Bergh (The Swedish National Council's protocol with support of state funds in printing issued by the Royal Swedish National Archives by Severin Bergh), IX. 1642, Part 3. Riksarkivet, Stockholm, Sweden.

Classen, Constance, David Howes, and Anthony Synnott

1994 Aroma: The Cultural History of Smell. Routledge, London, UK.

Cole, Jennifer

1998 The Work of Memory in Madagascar. American Ethnologist 25(4):610-633.

Connerton, Paul

2009 How Modernity Forgets. Cambridge University Press, Cambridge, UK.

Corburn, Jason

2004 Confronting the Challenges in Reconnecting Urban Planning and Public Health. American Journal of Public Health 94(4):541-546.

Elmgren, Sven

1847 Beskrifning öfver Pargas socken (A description of the Pargas parish). Pargas hembygdsförenings publikationer No. 6. Pargas, Finland.
Enbuske, Matti

2010 Pohjois-Pohjanmaan ympäristöhistoria: Alueellisen ympäristöhallinnon kehitys sekä ohjaavat järjestelmät, vaikuttavat tekijät ja ympäristövaikutukset (Environmental history of northern Ostrobothnia: Development of regional environmental management and guiding systems, influencing factors, and environmental impacts). PohjoisPohjanmaan ELY-keskus, Oulu, Finland.

Forsman, Juho R.

1899 Suomen kirkollisten olojen uudistus ison vihan jälkeen (Reform of churches in Finland after the Great Northern War). G. W. Wilén, Turku, Finland.

Hackzell, Mårten

1763 Geometrisk charta, Uhleåborgs Stadt (Geometric map, Oulu Town). Manuscript, Northern Ostrobothnia Museum, Oulu, Finland.

Halila, Aimo

1953 Oulun Kaupungin Historia II 1721-1809 (History of the town of Oulu II 1721-1809). Kirjola Oy, Oulu, Finland.

Hamilakis, Yannis

2013 Archaeology and the Senses: Human Experience, Memory, and Affect. Cambridge University Press, New York, NY.

Hautala, Kustaa

1975 Oulun Kaupungin Historia III 1809-1856 (History of the town of Oulu III 1809-1856). Oulun kaupunki, Oulu, Finland.

Heikkilä, Hilkka

2011 Oulun kaupungistumisen ympäristövaikutukset mikrofossiilianalyysin valossa (The environmental impacts of urbanization of the town of Oulu in the light of microfossil analysis). Master's thesis, Department of Archaeology, University of Oulu, Oulu, Finland.

Helamaa, Maija

2015 Oulu, Lyseon lukion piha. Kaupunkiarkeologiset tutkimukset 7.7.-31.9.2015 (Oulu, Lyseo High School yard. Urban archaeological excavations 7.7.-31.9.2015). Manuscript, Muuritutkimus ky, Kaarina, Finland.

Hellemaa, Lahja-Irene, Anja Jussila, and Martti Parvio (editors)

1986 Näköispainos ja uudelleen ladottu laitos vuoden 1686 kirkkolain suomennoksesta (Facsimile and reprint of the Finnish translation of the 1686 church law). Suomen Kirjallisuuden Seuran Toimituksia 444. WSOY, Juva, Finland.

Hjelt, Otto E. A.

1911 Johan Haartmans verksamhet vid universitetet $i$ Abo under aren 1754-1787 (Johan Haartman's activity at the University of Abo during the years 1754-1787). Finska Vetenskapssocieteten, Helsinki, Finland.

Howes, David

2006 Scent, Sound, and Synaesthesia: Intersensoriality and Material Culture Theory. In Handbook of Material Culture, Christopher Y. Tilley, Webb Keane, Susanne Küchler, Michael Rowlands, and 
Patricia Spyer, editors, pp. 161-172. Sage, London, UK.

Hydenius, Johan

1765 Tanckar om liks begrafwande $i$ kyrckor och kyrkogårdar (Thoughts about burying the deceased inside churches and churchyards). Joh. Christoph. Frenckell, Turku, Finland.

Jenner, Mark S. R.

2005 Death, Decomposition and Dechristianisation? Public Health and Church Burial in EighteenthCentury England. English Historical Review 120(487):615-632.

Jenner, Mark S. R.

2011 Follow Your Nose: Smell, Smelling, and Their Histories. American Historical Review 116(2):335-351.

Joutsivuo, Timo

2005 Medikalisoitu ilma: Kaupunki-ilman vaarat 1500 1700-lukujen lääketieteessä (Medicated air: The dangers of the urban air in 16th- to 17th-century medicine). In Kaupunkikuvia arjessa, Timo Joutsivuo and Markku Kekäläinen, editors, pp. 179-208. Suomalaisen Kirjallisuuden Seura, Helsinki, Finland.

Kallioinen, Mika

2009 Rutto ja rukous. Tartuntataudit esiteollisen ajan Suomessa (Plague and prayer. Infectious diseases in pre-industrial Finland). Atena, Jyväskylä, Finland.

Kallio-Seppä, Titta

2013 Kosteutta, puuta ja vallankäyttöä: Arkeologinen näkökulma Oulun kaupungin julkisen tilan kehittymiseen 1600-luvulta 1820-luvulle (Moisture, wood and power: An archaeological perspective on the development of the public space of Oulu from the 17 th to the 18th centuries). Pohjois-Suomen historiallinen yhdistys, Rovaniemi, Finland.

Karvosenoja, Heikki

1995 Seurakunnan ohjaus Oulun hautausmaan muotoutumisessa 1780-1930 (Control of the parish in the formation of the graveyard of Oulu 1780-1930). Licentiate thesis, Department of Practical Theology, University of Helsinki, Helsinki, Finland.

Kehusmaa, Aimo

1997 Oulun tuomiokirkon kaivaukset 1996. Kaivauskertomus (Excavations at the Oulu Cathedral 1996. Excavation report). Manuscript, Pohjois-Pohjanmaan museo, Oulu, Finland.

Kejserliga Senatens för Finland

1826 Förordningar, Manifester och Påbud, samt adre Allmänna Handlingar: Hwilka I Stor-Furstendömet Finland sedan 1808 års början ifrån trycket utkommit (Regulations, manifestations and orders, as well as other general documents: Published in the Grand Duchy of Finland since the beginning of 1808), 4. delen, 1821-1824. Kejserliga Senatens för Finland, Turku, Finland.

Keränen, Jorma

1977 Paltamon seurakunnan historia (History of the Paltamo parish). Paltamon seurakunta, Kiuruvesi, Finland.
Korhonen, Arvi

1929 Turun Tuomiokirkko vv. 1700-1827 (The cathedral of Turku yrs. 1700-1827). Turun Historiallisen Yhdistyksen Julkaisuja III, Turku, Finland.

Laasonen, Pentti

1991 Suomen kirkon historia II, vuodet 1593-1808 (History of the Finnish church II, years 15931808). WSOY, Porvoo, Finland.

Lagerås, Per

2016 Från trädgård till grav: Växterna i biskop Peder Winstrups kista (From garden to grave: Plants inside Bishop Peder Winstrup's coffin). Ale 4:1528.

Lehikoinen, Heikki

2011 Katkera Manalan Kannu: Kuoleman Kulttuurihistoria Suomessa (Bitter jug of Manala: The cultural history of death in Finland). Teos, Helsinki, Finland.

Lempiäinen, Pentti

1990 Hautausmaaperinteen rikkaus (Richness of the cemetery tradition). In Viimeiset leposijamme. Hautausmaat ja hautamuistomerkit, Pentti Lempiäinen and Brita Nickels, editors, pp. 7-20. SLEY-Kirjat, Imatra, Finland.

Leone, Mark P.

1999 Ceramics from Annapolis, Maryland: A Measure of Time Routines and Work Discipline. In Historical Archaeologies of Capitalism, Mark P. Leone and Jocelyn E. Knauf, editors, pp. 195-216. Kluwer Academic, New York, NY.

Mäntylä, Ilkka

1971 Tornion historia I 1621-1809 (History of Tornio I 1621-1809). Tornion kaupunki, Tornio, Finland.

Matthews, Christopher N., Mark P. Leone, and Kurt A. Jordan

2002 The Political Economy of Archaeological Cultures: Marxism and American Historical Archaeology. Journal of Social Archaeology 2(1):109-134.

Modée, Reinhold Gustaf

1803 Utdrag Utur alle ifrain år 1783 utkomne Publique Handlingar, Placater, Förordningar, Resolutioner och Publicationer (Excerpts of all publications published in 1783, placats, regulations, resolutions and publications). Kongl. Tryckeriet, Stockholm, Sweden.

Nikander, Gabriel

1945 Kokkolan Kaupungin Historia II 1714-1808 (History of the town of Kokkola II 1714-1808). Kokkolan kaupunki, Kokkola, Finland.

Nordberg, Albert

1970 En gammal Norrbottensbygd. Anteckningar till Luleå sockens historia II (An old village in Norrbotten. Notes on the history of Luleå). Norrbottens museum, Luleå, Sweden.

Nyberg, Jenny

2010 A Peaceful Sleep and Heavenly Celebration for the Pure and Innocent. The Sensory Experience of Death during the Long Eighteenth Century. In Making Sense of Things: Archaeologies of Sensory Perception, Fredrik Fahlander and Anna Kjellström, editors, pp. 15-33. Stockholm University, Stockholm, Sweden. 
Onnela, Samuli

1982 Oulun hautausmaa (The graveyard of Oulu). Oulun evankelis-luterilainen seurakunnat, Oulu, Finland.

Paavola, Kirsti

1988 Domus pro tempo: Hailuodon kirkon varhaisvaiheet (Domus pro tempo: Early stages of the history of Hailuoto Church). In Hailuodon Keskiaika, Kyösti Julku and Reija Satokangas, editors, pp. 9-34. Pohjois-Suomen historiallinen yhdistys, Rovaniemi, Finland.

Paavola, Kirsti

1995 Kepeät Mullat — Kirjallisiin ja Esineellisiin Lähteisiin Perustuva Tutkimus Hailuodon Kirkkohaudoista (Light soils - study of the church burials on the coast of northern Ostrobothnia based on written and material sources). Licentiate thesis, Department of General History, University of Oulu, Oulu, Finland.

Paavola, Kirsti

1998 Kepeät mullat. Kirjallisiin ja esineellisiin lähteisiin perustuva tutkimus Pohjois-Pohjanmaan rannikon kirkkohaudoista (Light soils. Study of the church burials on the coast of northern Ostrobothnia based on written and material sources). Acta Universitatis Ouluensis B Humaniora 28. Oulu, Finland.

Palmer, Richard

1993 In Bad Odour: Smell and Its Significance in Medicine from Antiquity to the Seventeenth Century. In Medicine and the Five Senses, W. F. Bynum and Roy Porter, editors, pp. 61-68. Cambridge University Press, Cambridge, UK.

Palola, Ari-Pekka

2000 Oulun Kirkkohistoria I vuoteen 1870. Kirkko Keskellä Kaupunkia (Oulu church history I until 1870. Church in the middle of the city). Oulun evankelis-luterilainen seurakuntayhtymä, Oulu, Finland.

Pawlowska, Kamilla

2014 The Smells of Neolithic Çatalhöyük, Turkey: Time and Space of Human Activity. Journal of Anthropological Archaeology 36:1-11.

Piippo, Sinikka

2008 Kasvien Salaiset Voimat (Secret powers of plants). Helmi Kustannus, Porvoo, Finland.

Pylkkänen, Riitta

1954 Isonkyrön vanha kirkko (Old church of Isokyrö). Isonkyrön seurakunta, Isokyrö, Finland.

Reinarz, Jonathan

2014 Past Scents: Historical Perspectives on Smell. University of Illinois Press, Champaign.

Riley, James C.

1987 The Eighteenth-Century Campaign to Avoid Disease. Macmillan, London, UK.

Rinne, Juhani, and Karl K. Meinander

1912 Bidrag till Vasa Stads Historia I (Contribution to Vaasa City's history I). Föreningen för Österbottens Historiska Museum, Helsinki, Finland.

Ruoff, Eeva

2003 Tuoksujen Puutarha (Garden of scents). Otavan Kirjapaino Oy, Keuruu, Finland.
Salmi, Anna-Kaisa, Annemari Tranberg, Mirva Pääkkönen, and Risto Nurmi

2014 Becoming Modern: Hybrid Foodways in Early Modern Tornio, Northern Finland. International Journal of Historical Archaeology 18(3):489-512.

Sarkkinen, Mika, and Aimo Kehusmaa

2002 Oulun Tuomiokirkon Kirkkotarhasta (About Oulu Cathedral cemetery). Manuscript, Northern Ostrobothnia Museum, Oulu, Finland.

Snellmann, Johannes

2000 De urbe Uloa-Oulun kaupungista (About Oulu town). Oulu-seura, Scripta Historica 28. Oulu, Finland.

Suolahti, Gunnar

1917 Elämää Suomessa 1700-luvulla (Life in Finland in the 18th century), Vol. 2. WSOY, Porvoo, Finland.

Susser, Mervyn, and Ezra Susser

1996 Choosing a Future for Epidemiology: 1. Eras and Paradigms. American Journal of Public Health 86(5):668-673.

Tarlow, Susan

2007 The Archaeology of Improvement in Britain 1750 1850. Cambridge University Press, New York, NY.

Thorsheim, Peter

2006 Inventing Pollution: Coal, Smoke, and Culture in Britain since 1800. Ohio University Press, Athens.

Tidningar Utgife Af et Sällskap i Åbo

1773 Anmärkning om liks begrafvande i kyrkor (Remarks about burying the deceased in churches). Tidningar Utgife Af et Sällskap i Åbo 14 February, 3:22-23. Turku, Finland.

Tidningar Utgife Af et Sällskap $i$ Åbo

1777 Anmärkningar öfver det wedertagna bruket, att begrafwa lik i kyrkor och inom städers omkrets (Remarks about the accepted practice of burying the deceased in churches and within the town borders). Tidningar Utgife Af et Sällskap i Åbo 31 October, 20:152-156. Turku, Finland.

Tranberg, Annemari

2018 Ympäristön ja ihmisen suhteen muuttuminen Perämeren rannikolla varhaismodernina aikana. Makrofossiilitutkimus kasvien käytöstä muuttuvassa maailmassa (Changes in the relationship between the environment and humans on the Gulf of Bothnia coast in early modern times. Macrofossil research on the use of plants in a changing world). Acta Universitatis Ouluensis B Humaniora 161. Oulu, Finland.

Vahtola, Jouko

1991 Oulujokilaakson historia keskiajalta 1860-luvulle (History of Oulu River valley area from medieval times to the 1860s). In Oulujokilaakson historia. Kivikaudelta vuoteen 1865, Matti Huurre and Jouko Vahtola, editors, pp. 71-604. Oulujokilaakson historiatoimikunta, Oulu, Finland.

Virkkunen, Artturi H.

1953 Oulun Kaupungin historia I, Kaupungin alkuajoilta Isonvihan loppuun (History of the Town of Oulu I, from the beginning to the end 
of the Great Northern War), 2nd edition. Oulun kaupunki, Oulu, Finland.

Virrankoski, Pentti

1973 Pohjois-Pohjanmaan ja Lapin historia III, PohjoisPohjanmaa ja Lappi 1600-luvulla (History of northern Ostrobothnia and Lapland III, northern Ostrobothnia and Lapland in the 17th century). Pohjois-Pohjanmaan, Kainuun ja Lapin maakuntaliittojen yhteinen historiatoimikunta, Oulu, Finland.

Vuorinen, Heikki S.

2010 Taudit, Parantajat ja Parannettavat. Lääketieteellinen Historia (Diseases, healers and cures. Medical history). Vastapaino, Tampere, Finland.

Warelius, Antero

1861 Saatanto Tuonelaa, eli Ilmoitteita miten meikäläiset kuolleen-korjaus-tawat owat muodostuneet (Farewell to the underworld, the ways burial traditions are formed). Frenckell, Turku, Finland.

Wilskman, Sven

1782 Swea Rikes Ecclesiastique Werk I Alphabetisk Ordning Sammandragit Utur Lag och Förordningar, Privilegier och Resolutioner, Samt Andra Handlingar (Swedish kingdom's ecclesiastical work I alphabetical order of laws and regulations, privileges and resolutions, and other documents), Senare delen. Joh. Henrich Werner, Örebro, Sweden.

Publisher's Note Springer Nature remains neutral with regard to jurisdictional claims in published maps and institutional affiliations. 